\title{
Paget disease of the nipple
}

INSERM

\section{Source}

INSERM. (1999). Orphanet: an online rare disease and orphan drug data base. Paget disease of the nipple. ORPHA:180275

Paget disease of the nipple describes a rare presentation of breast cancer, seen most frequently in women aged 50-60, manifesting with nipple drainage and itching, erythema, crusty and excoriated nipple, thickened plaques, and hyperpigmentation (less frequently). It is due to tumor cells invading the nipple-areola complex and represents 1-3\% of all new breast cancer diagnoses. 